\title{
ANALISIS KESALAHAN GRAMATIKAL PENULISAN ABSTRAK BERBAHASA INGGRIS PADA BEBERAPA JURNAL DI LINGKUNGAN POLITEKNIK NEGERI JEMBER
}

\author{
Oleh: \\ AGUS SETIA BUDI*
}

\begin{abstract}
ABSTRAK
Penelitian ini dilaksanakan di Politeknik Negeri Jember. Penelitian ini dilaksanakan untuk memberikan gambaran secara jelas dan tepat tentang kemampuan dosen dalam menulis abstrak dengan menggunakan Bahasa Inggris. Tujuan dari penelitian ini adalah untuk mengetahui jenis-jenis kesalahan gramatikal apa saja yang terdapat dalam penulisan abstrak berbahasa Inggris pada beberapa jurnal di lingkungan Politeknik Negeri Jember. Penelitian ini menggunakan pendekatan diskriptif kualitatif. Penelitian ini dilaksanakan untuk memperoleh gambaran tentang gambaran yang tepat tentang jenisjenis kesalahan penggunaan Bahasa Inggris sebagai bahasa asing oleh dosen dalam menulis abstrak berbahasa Inggris. Penelitian ini dimulai dari masalah (problem) dan landasan teori. Data yang diperoleh dalam penelitian ini adalah data sekunder yaitu berupa tulisan abstrak berbahasa Inggris dari dari artikel yang dimuat pada beberapa jurnal yang ada di lingkungan Politeknik Negeri Jember. Sedangkan sampel dalam penelitian ini diambil dengan sampling acak strata (Stratified Random Sampling). Data yang diperoleh kemudian dianalisa dengan menggunakan Teknik Analisa Diskriptif (Descriptive Analysis Technique).
\end{abstract}

Kata kunci: analisa kesalahan, gramatikal, menulis, abstrak, jurnal

* Staf Pengajar pada jurusan Bahasa, Komunikasi dan Pariwisata, Politeknik Negeri Jember. 


\section{PENDAHULUAN}

Keterampilan menulis dianggap rumit dan kompleks karena menulis merupakan media komunikasi yang menggunakan tanda dan simbol yang meliputi huruf, tanda baca dan spasi untuk mengkomunikasikan pikiran dan ide dalam bentuk tulisan. Selain itu, dalam sistem sebuah bahasa, menulis sangat berkaitan langsung dengan aspekaspek bahasa seperti kosakata, tata bahasa, dan semantik. Sehingga untuk dapat menulis dengan baik perlu memahami sistem sebuah bahasa yang digunakan dalam kegiatan menulis tersebut. Seperti yang dinyatakan oleh Sarfraz (2011) bahwa menulis adalah sebuah aktivitas yang sangat kompleks dan menulis dengan menggunakan bahasa asing seperti Bahasa Inggris akan menjadi lebih rumit lagi karena memerlukan kemampuan untuk menyusun dan mengembangkan ide yang logis sehingga menjadi sebuah teks yang dapat dimengerti dan dipahami oleh pembaca.

Sebagai bahasa internasional, Bahasa Inggris merupakan salah satu bahasa yang paling dominan digunakan dalam komunikasi baik secara lisan maupun tulisan. Secara tulisan, Bahasa Inggris banyak digunakan dalam penulisan buku-buku teks dan artikel-artikel yang dimuat di jurnal internasional. Ada beberapa alasan mengapa buku atau artikel harus ditulis dalam Bahasa Inggris seperti yang dinyatakan oleh Ingale (2013) antara lain karena Bahasa Inggris merupakan bahasa yang dominan dan mempunyai jangkauan luas sehingga dapat dibaca dan dikenali oleh banyak orang. Bahkan artikel yang dimuat di jurnal nasional, walaupun artikelnya ditulis dengan menggunakan Bahasa Indonesia akan tetapi abstraknya harus ditulis dengan menggunakan Bahasa Inggris. Hal ini dilakukan dengan tujuan bahwa abstrak yang ditulis dalam bahasa Inggris dapat mempermudah untuk memperkenalkan artikel tersebut kepada kalangan yang lebih luas.

Menulis abstrak dalam Bahasa Inggris menjadi sebuah kendala bagi beberapa penulis terutama bagi mereka yang tidak mempunyai kebiasaan menulis dengan menggunakan Bahasa Inggris. Hal ini terjadi karena untuk memiliki keterampilan menulis dalam Bahasa Inggris dengan baik tidak hanya dapat diperoleh secara alami dan otomatis. Keterampilan ini harus diperoleh dengan banyak belajar dan latihan. Blanchard and Root (1997) menyatakan bahwa tidak seorangpun yang dilahirkan sebagai seorang penulis karena ketrampilan menulis harus dipelajari dan dilatih melalui sebuah proses pengalaman. Selain faktor kurangnya latihan dan pengalaman menulis dalam Bahasa Inggris, Ridha (2012) juga menyatakan bahwa alasan mengapa menulis dalam Bahasa Inggris dianggap paling sulit untuk dikuasai adalah karena menulis merupakan proses yang kompleks yang memerlukan analisa kognitif dan sintesis linguistik. Akan menjadi lebih rumit lagi jika menulis dalam bahasa asing seperti Bahasa Inggris karena setiap bahasa mempunyai tata bahasa atau gramatikal yang harus dipahami dan diikuti.

Kesalahan Umum Gramatikal (Common Error) yang biasa terjadi ketika menulis dalam Bahasa Inggris sebagai bahasa asing seperti yang dinyatakan oleh Yulianti (2007) membagi menjadi tiga katagori kesalahan gramatikal yaitu: (1) subject and verb, (2) verb agreement, tense, dan form, and (3) pronoun. Sedangkan King \& Stanley (1999) menyebutkan bahwa kesalahan yang berkaitan dengan struktur kalimat adalah: (1) subject and verb, (2) verb agreement, tense, and form, (3) full subordination, (4) verbal, (5) pronoun form, agreement, and reference, (6) word form, (7) word order, (8) parallel structure, (9) unnecessary repetition, dan (10) correct usage. Kemudian Huang (2001) menginvestigasi kesalahan gramatikal dan menemukan enam kesalahan umum dalam menulis yaitu: (1) Verb (2) Noun (3) Spelling (4) Article (5) Preposition and (6) Word Choice.

Kesalahan merupakan bagian dari proses belajar bahasa asing yang dilakukan oleh pengguna bahasa yang disebabkan oleh kemampuan mereka yang kurang dalam memahami aturan bahasa asing yang digunakan tersebut. Menurut Brown (2000) kesalahan adalah bagian dari tingkat perkembangan belajar bahasa untuk menuju penguasaan bahasa yang sepenuhnya. Kemudian Dulay et. al. (1982) menyatakan bahwa kesalahan merupakan bagian yang menunjukkan kekurangan dari pengguna bahasa dalam menggunakan bahasa baik secara lisan maupun tulis. Kesalahan tersebut merupakan hal yang menyimpang dari norma penggunaan bahasa yang sempurna. Ketika pengguna bahasa belajar menggunakan bahasa asing, mereka akan membuat banyak kesalahan dalam penggunaan bahasa asing tersebut. Ini merupakan hal yang wajar dalam proses penguasaan bahasa. Untuk mengetahui kesalahankesalahan dalam pengunaan bahasa tersebut maka diperlukan analisis kesalahan (error analysis).

Dalam linguistik, analisis kesalahan (error analysis) adalah kajian yang dilaksanakan terhadap sebuah bahasa guna meneliti kekeliruan struktur bahasa tersebut secara mendalam. Menurut Crystal (1981) mengungkapkan bahwa analisis kesalahan adalah sebuah teknik untuk mengidentifikasi secara sistematis kesalahan-kesalahan yang dibuat oleh pengguna bahasa yang menggunakan bahasa 
asing dengan menggunakan teori-teori atau prosedur-prosedur berdasarkan linguistik. Jadi, analisis kesalahan adalah suatu teknik yang digunakan oleh untuk mengidentifikasi kesalahan, mengevaluasi kesalahan dan mengklarifikasi kesalahan dalam bahasa seperti contoh pemakaian bentuk-bentuk aturan unit kebahasaan yang meliputi kata, paragraf, kalimat yang menyimpang dari sistem ejaan dan tanda baca yang telah di tetapkan. Kemudian menurut Hasyim (2002) analisa kesalahan dilakukan dengan tujuan untuk: (1) mengetahui bagaimana penguna bahasa menguasai bahasa, (2) mengetahui bagaimana pengguna bahasa belajar sebuah bahasa, dan (3) mendapatkan informasi tentang kesalahankesalahan umum dalam penggunaan bahasa. Informasi tentang hal tersebut di atas dapat diperoleh melalui analisis kesalahan karena analisis kesalahan merupakan sebuah proses observasi, analisis dan klasifikasi penyimpangan tata bahasa asing atau bahasa kedua dalam hal ini adalah Bahasa Inggris yang ditunjukkan oleh pengguna bahasa tersebut (Brown dalam Hasyim, 2002).

Berdasarkan uraian di atas, maka tujuan dari penelitian ini adalah untuk mengidentifikasi dan menganalisis jenis-jenis kesalahan gramatikal yang terdapat dalam penulisan abstrak berbahasa Inggris pada beberapa jurnal di lingkungan Politeknik Negeri Jember.

\section{METODOLOGI}

Penelitian ini dilaksanakan di Politeknik Negeri Jember yang berlokasi di Jalan Mastrip PO. Box. 164 Jember. Subjek penelitian ini adalah para dosen yang ada di lingkungan Politeknik Negeri Jember.

Penelitian ini adalah penelitian diskriptif dengan menggunakan pendekatan kualitatif. Penelitian ini dilaksanakan untuk memperoleh gambaran tentang gambaran yang tepat tentang jenis-jenis kesalahan penggunaan Bahasa Inggris sebagai bahasa asing oleh dosen dalam menulis abstrak berbahasa Inggris

Data yang diperoleh dalam penelitian ini adalah data sekunder yaitu berupa tulisan abstrak berbahasa Inggris dari dari artikel yang dimuat pada beberapa jurnal yang ada di lingkungan Politeknik Negeri Jember. Data sekunder yaitu data yang dikumpulkan, diolah, dan disajikan oleh pihak lain, yang biasanya sudah ada dalam bentuk dokumen.

Sedangkan populasi pada penelitian ini adalah dosen di lingkungan Politeknik Negeri Jember. Dosen tersebut adalah dosen yang menulis abstrak berbahasa Inggris pada beberapa jurnal di lingkungan Politeknik Negeri Jember.
Cara mengambil sampel dalam penelitian ini adalah dengan sampling acak strata (Stratified Random Sampling). Cara ini digunakan populasi heterogen, dalam populasi heterogen tersebut ternyata ada strata-strata yang homogen. Sampel yang diambil dalam penelitian ini adalah 30 abstrak berbahasa Inggris dari artikel yang dimuat di beberapa jurnal yang berbeda di lingkungan Politeknik Negeri Jember.

Data dikumpulkan dengan cara mengunjungi perpustakaan Politeknik Negeri Jember. Kemudian peneliti membaca dan memilih secara acak abstrak berbahasa Inggris dalam jurnal yang ada di perpustakaan tersebut. Jurnal yang dipilih adalah jurnal yang terbit mulai tahun 2000 sampai tahun 2014. Dari masing-masing jurnal diambil sebanyak 2 abstrak.

Dalam menganalisa data, peneliti menggunakan Teknik Analisa Diskriptif (Descriptive Analysis Technique) dengan menggunakan rumus sebagai berikut:

$$
P=\frac{F}{\mathbf{N}} \times 100 \%
$$

$$
\begin{aligned}
& \mathrm{P}=\text { Prosentase } \\
& \mathrm{F}=\text { Frekuensi Kesalahan } \\
& \mathrm{N}=\text { Jumlah Sample }
\end{aligned}
$$

\section{HASIL DAN PEMBAHASAN}

Berdasarkan hasil yang diperoleh dalam penelitian ini dengan sample berjumlah 30 abstrak berbahasa Inggris dari artikel yang dimuat di beberapa jurnal yang berbeda di lingkungan Politeknik Negeri Jember, ditemukan beberapa jenis kesalahan-kesalahan gramatikal yang dilakukan oleh dosen dalam menulis abstrak berbahasa Inggris. Kesalahan-kesalahan gramatikal tersebut meliputi kesalahan Subject/Verb Agreement (Kesesuaian Subyek dan Kata Kerja) menempati urutan pertama dengan tingkat kesalahan $70 \%$ dari 30 abstrak yang diteliti. Jenis kesalahan ini merupakan kesalahan yang sering terjadi dalam penulisan abstrak berbahasa Inggris yang dilakukan oleh dosen di lingkungan Politeknik Negeri Jember. Urutan kedua ditempati oleh jenis kesalahan penggunaan Article (Kata Sandang) dengan tingkat kesalahan $56,7 \%$ dan kesalahan penggunaan Preposition (Kata Depan) dengan tingkat kesalahan 53,3\%. Kemudian jenis kesalahan lain yang juga sering ditemui adalah Run-on Sentence (Penggabungan Kalimat) denngan tingkat kesalahan 46,6\% dan Word Order (Penyusunan Kata) dengan tingkat keslahan 43,3\%. Sedangkan jenis kesalahan lain yang jarang terjadi adalah Possessive (Kata Ganti Milik) dan 
Redundancy (Pengulangan Kata) dengan tingkat kesalahan 10\%. Dari kesalahan-kesalahan tersebut terdapat kesalahan yang paling sedikit ditemui yaitu kesalahan penggunaan Pronoun Agreement (Kata Ganti), Parallelism (Kesejajaran) dan Regularization (Penyamaan Aturan) masingmasing dengan tingkat kesalahan sebesar $6,7 \%$.

Data tentang jenis-jenis kesalahan di penulisan abstrak berbahasa Inggris oleh dosen di lingkungan Politeknik Negeri Jember lebih jelasnya dapat dilihat di tabel berikut ini:

\begin{tabular}{|c|c|c|c|}
\hline $\begin{array}{l}\text { No } \\
\text {. }\end{array}$ & Jenis Kesalahan & $\begin{array}{c}\text { Jumlah } \\
\text { Kesalahan }\end{array}$ & $\begin{array}{l}\text { Prosen } \\
\text { tase }\end{array}$ \\
\hline 1. & $\begin{array}{l}\text { Part of Speech } \\
\text { (Jenis Kata) }\end{array}$ & 11 & $36,7 \%$ \\
\hline 2. & $\begin{array}{l}\text { Subject/Verb } \\
\text { Agreement } \\
\text { (Kesesuaian } \\
\text { Subyek dan Kata } \\
\text { Kerja) }\end{array}$ & 21 & $70 \%$ \\
\hline 3. & $\begin{array}{c}\text { Preposition } \\
\text { (Kata Depan) }\end{array}$ & 16 & $53,3 \%$ \\
\hline 4. & $\begin{array}{l}\text { Pronoun } \\
\text { Agreement (Kata } \\
\text { Ganti) }\end{array}$ & 2 & $6,7 \%$ \\
\hline 5. & $\begin{array}{l}\text { Passive } \\
\text { Construction } \\
\text { (Kalimat Pasif) }\end{array}$ & 9 & $30 \%$ \\
\hline 6. & $\begin{array}{l}\text { Apostrophe/Poss } \\
\text { essive (Kata } \\
\text { Ganti Milik) }\end{array}$ & 3 & $10 \%$ \\
\hline 7. & $\begin{array}{l}\text { Colon (Tanda } \\
\text { Baca) }\end{array}$ & 6 & $20 \%$ \\
\hline 8. & $\begin{array}{l}\text { Parallelism } \\
\text { (Kesejajaran) }\end{array}$ & 2 & $6,7 \%$ \\
\hline 9. & $\begin{array}{l}\text { Run-on Sentence } \\
\text { (Penggabungan } \\
\text { Kalimat) }\end{array}$ & 14 & $46,6 \%$ \\
\hline 10. & $\begin{array}{l}\text { Fragments } \\
\text { (Kalimat Tidak } \\
\text { Lengkap) }\end{array}$ & 3 & $10 \%$ \\
\hline 11. & $\begin{array}{l}\text { Article (Kata } \\
\text { Sandang) }\end{array}$ & 17 & $56.7 \%$ \\
\hline 12. & $\begin{array}{l}\text { Spelling } \\
\text { (Pengejaan) }\end{array}$ & 12 & $40 \%$ \\
\hline 13. & $\begin{array}{l}\text { Regularization } \\
\text { (Penyamaan } \\
\text { Aturan) }\end{array}$ & 2 & $6,7 \%$ \\
\hline 14. & $\begin{array}{l}\text { Verb Tense (Kata } \\
\text { Kerja Waktu) }\end{array}$ & 18 & $60 \%$ \\
\hline 15. & $\begin{array}{l}\text { Word Choice } \\
\text { (Pilihan Kata) }\end{array}$ & 10 & $33,3 \%$ \\
\hline 16. & $\begin{array}{l}\text { Singular/Plural } \\
\text { (Tunggal/Jamak) }\end{array}$ & 14 & $46,7 \%$ \\
\hline 17. & Word Order & 13 & $43,3 \%$ \\
\hline
\end{tabular}

\begin{tabular}{|c|l|r|r|}
\hline & $\begin{array}{l}\text { (Penyusunan } \\
\text { Kata) }\end{array}$ & & \\
\hline 18. & $\begin{array}{l}\text { Redundancy } \\
\text { (Pengulangan } \\
\text { Kata) }\end{array}$ & 3 & $10 \%$ \\
\hline 19. & $\begin{array}{l}\text { Addition } \\
\text { (Penambahan } \\
\text { Kata) }\end{array}$ & 10 & $33,3 \%$ \\
\hline 20. & $\begin{array}{l}\text { Omission } \\
\text { (Penghilangan } \\
\text { Kata) }\end{array}$ & 16 & $53,3 \%$ \\
\hline
\end{tabular}

Jenis-jenis kesalahan gramatikal dalam penulisan abstrak berbahasa Inggris oleh dosen di lingkungan Politeknik Negeri Jember pada tabel di atas dapat dijabarkan sebagai berikut:

\section{Part of Speech (Jenis Kata)}

Berdasarkan tabel di atas diketahui bahwa kesalahan penggunaan Part of Speech (Jenis Kata) dalam penulisan abstrak sebesar $36,7 \%$ dari 30 abstrak yang diteliti. Ini berarti dari 30 responden terdapat 11 responden yang melakukan jenis kesalahan ini.

Contoh kesalahan penggunaan Part of Speech (Jenis Kata) dalam penulisan abstrak:

Salah: In this research, OLAP was used to identify agricultural produce distribution in sub-province of Jember.

Benar: In this research, OLAP was used to identify agricultural product distribution in sub-province of Jember.

\section{Subject/Verb Agreement (Kesesuaian Subjek dan Kata Kerja)}

Berdasarkan tabel di atas diketahui kesalahan Subject/Verb Agreement (Kesesuaian Subyek dan Kata Kerja) dalam penulisan abstrak sebesar $70 \%$ dari 30 abstrak yang diteliti. Ini berarti dari 30 responden terdapat 21 responden yang melakukan jenis kesalahan ini.

Contoh kesalahan penggunaan Subject/Verb Agreement (Kesesuaian Subyek dan Kata Kerja) dalam penulisan abstrak:

Salah: The second factor were fruit maturity.

Benar: The second factor was fruit maturity.

\section{Preposition (Kata Depan)}

Berdasarkan tabel di atas diketahui kesalahan penggunaan Preposition (Kata Depan) dalam penulisan abstrak sebesar 53,3\% dari 30 abstrak yang diteliti. Ini berarti dari 30 responden terdapat 16 responden yang melakukan jenis kesalahan ini.

Contoh kesalahan penggunaan Preposition (Kata Depan) dalam penulisan abstrak: 
Salah: The quality management system of ISO 9000 is a unique document which it can be applied on all business sectors.

Benar: The quality management system of ISO 9000 is a unique document which it can be applied for all business sectors.

\section{Pronoun Agreement (Kata Ganti)}

Berdasarkan tabel di atas diketahui kesalahan Pronoun Agreement (Kata Ganti) dalam penulisan abstrak sebesar $6,7 \%$ dari 30 abstrak yang diteliti. Ini berarti dari 30 responden terdapat 2 responden yang melakukan jenis kesalahan ini.

Contoh kesalahan penggunaan Pronoun Agreement (Kata Ganti) dalam penulisan abstrak:

Salah: The treatment was done for fourteen day old quails until its had sexual maturity.

Benar: The treatment was done for fourteen day old quails until they had sexual maturity.

\section{Passive Construction (Kalimat Pasif)}

Berdasarkan tabel di atas diketahui kesalahan Passive Voice (Bentuk Pasif) dalam penulisan abstrak sebesar 30\% dari 30 abstrak yang diteliti. Ini berarti dari 30 responden terdapat 9 responden yang melakukan jenis kesalahan ini.

Contoh kesalahan penggunaan Passive Construction (Kalimat Pasif) dalam penulisan abstrak:

Salah: The research carried out to know the factors that influence the famer's cability in managing the marginal land.

Benar: The research was carried out to know the factors that influence the famer's cability in managing the marginal land.

\section{Apostrophe/Possessive Adjectives (Kata Ganti Milik)}

Berdasarkan tabel di atas diketahui kesalahan Apostrophe/Possessive Adjectives (Kata Ganti Milik) dalam penulisan abstrak sebesar $10 \%$ dari 30 abstrak yang diteliti. Ini berarti dari 30 responden terdapat 3 responden yang melakukan jenis kesalahan ini.

Contoh kesalahan penggunaan Apostrophe/Possessive Adjectives (Kata Ganti Milik) dalam penulisan abstrak:

Salah: $\quad$ To increase the quantity and quality of cut flowers that match with the concumer demand, the farmer needs to attempt special post harvest treatment.
Benar: To increase the quantity and quality of cut flowers that match with the concumer's demand, the farmer needs to attempt special post harvest treatment.

\section{Colon (Tanda Baca)}

Berdasarkan tabel di atas diketahui kesalahan Colon (Tanda baca) dalam penulisan abstrak sebesar $20 \%$ dari 30 abstrak yang diteliti. Ini berarti dari 30 responden terdapat 6 responden yang melakukan jenis kesalahan ini.

Contoh kesalahan penggunaan Colon (Tanda baca) dalam penulisan abstrak:

Salah: The result of this research indicated (1) the combination of biological agents, $B . \quad$ Bassiana + S.Carpocapsae was more effective to reduce foliar damagae caused by $S$. Litura (2) the application of biological agents can decrease the production of damage fruit.

Benar: The result of this research indicated: (1) the combination of biological agents, $B . \quad$ Bassiana + S.Carpocapsae was more effective to reduce foliar damagae caused by $S$. Litura, (2) the application of biological agents can decrease the production of damage fruit.

\section{Parallelism (Kesejajaran)}

Berdasarkan tabel di atas diketahui kesalahan Parallelism (Kesejajaran) dalam penulisan abstrak sebesar $6,7 \%$ dari 30 abstrak yang diteliti. Ini berarti dari 30 responden terdapat 2 responden yang melakukan jenis kesalahan ini.

Contoh kesalahan tentang Parallelism (Kesejajaran) dalam penulisan abstrak:

Salah: The measurement of agronomic character included plant height, the number of primary branches, flowering period, and harvesting period.

Benar: The measurement of agronomic character included the height of plant, the number of primary branches, and the period of harvesting.

\section{Run-on Sentence (Penggabungan Kalimat)}

Berdasarkan tabel di atas diketahui kesalahan Run-on Sentence (Penggabungan Kalimat) dalam penulisan abstrak sebesar $46,6 \%$ dari 30 abstrak yang diteliti. Ini berarti dari 30 responden terdapat 14 responden yang melakukan jenis kesalahan ini. 
$\begin{array}{crr}\text { Contoh kesalahan penggunaan } & \text { Run-on } \\ \text { Sentence (Penggabungan } & \text { Kalimat) } & \text { dalam }\end{array}$ penulisan abstrak:

Salah: The study was conducted to identify marketing channel, marketing margin, and factors influencing marketing margin.

Benar: The study was conducted to identify marketing channel, marketing margin, and factors which influencing marketing margin.

\section{Fragments (Kalimat Tidak Lengkap)}

Berdasarkan tabel di atas diketahui kesalahan Fragments (Kalimat Tidak Lengkap) dalam penulisan abstrak sebesar $10 \%$ dari 30 abstrak yang diteliti. Ini berarti dari 30 responden terdapat 3 responden yang melakukan jenis kesalahan ini.

Contoh kesalahan yang berkaitan dengan Fragments (Kalimat Tidak Lengkap) dalam penulisan abstrak:

Salah: The research on the application of cheap fish nuggets production by using deboning enzyme method.

Benar: The research was about the application of cheap fish nugget production by using deboning enzyme method.

\section{Article (Kata Sandang)}

Berdasarkan tabel di atas diketahui kesalahan Article (Kata Sandang) dalam penulisan abstrak sebesar $56,7 \%$ dari 30 abstrak yang diteliti. Ini berarti dari 30 responden terdapat 17 responden yang melakukan jenis kesalahan ini.

Contoh kesalahan penggunaan Article (Kata Sandang) dalam penulisan abstrak:

Salah: This research was an survey research which was used for explanatory or confirmatory purpose.

Benar: This research was a survey research which was used for explanatory or confirmatory purpose.

\section{Spelling (Pengejaan)}

Berdasarkan tabel di atas diketahui kesalahan Spelling (Pengejaan) dalam penulisan abstrak sebesar $40 \%$ dari 30 abstrak yang diteliti. Ini berarti dari 30 responden terdapat 12 responden yang melakukan jenis kesalahan ini.

Contoh kesalahan Spelling (Pengejaan) dalam penulisan abstrak:

Salah: Gluten is very importent to build spongy structure of bread.

Benar: Gluten is very important to build spongy structure of bread.

\section{Regularalization (Penyamaan Aturan)}

Berdasarkan tabel di atas diketahui kesalahan Regularalization (Penyamaan Aturan) dalam penulisan abstrak sebesar 6,7\% dari 30 abstrak yang diteliti. Ini berarti dari 30 responden terdapat 2 responden yang melakukan jenis kesalahan ini.

Contoh kesalahan Regularalization (Penyamaan Aturan) dalam penulisan abstrak:

Salah: After conducting this research, it was showed that microbial pesticide is toxid and effective to control $H$. Hampei with LC50: $0.403 \%$.

Benar: After conducting this research, it was shown that microbial pesticide is toxid and effective to control $\mathrm{H}$. Hampei with LC50: 0.403\%.

\section{Verb Tense (Kata Kerja Waktu)}

Berdasarkan tabel di atas diketahui kesalahan Verb Tense (Kata Kerja Waktu) dalam penulisan abstrak sebesar $60 \%$ dari 30 abstrak yang diteliti. Ini berarti dari 30 responden terdapat 18 responden yang melakukan jenis kesalahan ini.

Contoh kesalahan Verb Tense (Kata Kerja Waktu) dalam penulisan abstrak:

Salah: This research is aimed to determine the factors influencing the demand of national sugar.

Benar: This research was aimed to determine the factors influencing the demand of national sugar.

\section{Word Choice (Pilihan Kata)}

Berdasarkan tabel di atas diketahui kesalahan Word Choice (Pilihan Kata) dalam penulisan abstrak sebesar $60 \%$ dari 30 abstrak yang diteliti. Ini berarti dari 30 responden terdapat 18 responden yang melakukan jenis kesalahan ini.

Contoh kesalahan dalam Word Choice (Pilihan Kata) dalam penulisan abstrak:

Salah: The value of coeffient correlation obtained was 0.9 .

Benar: The score of coeffient correlation obtained is 0.9 .

\section{Singular/Plural (Tunggal dan Jamak)}

Berdasarkan tabel di atas diketahui kesalahan Singular/Plural (Tunggal dan Jamak) dalam penulisan abstrak sebesar $46,7 \%$ dari 30 abstrak yang diteliti. Ini berarti dari 30 responden terdapat 14 responden yang melakukan jenis kesalahan ini. Contoh kesalahan Singular/Plural (Tunggal dan Jamak) dalam penulisan abstrak:

Salah: Agriculture Product are perishable product, so they need a good handling of post harvest. 
Benar: Agriculture Products are perishable products, so they need a good handling of post harvest.

\section{Word Order (Susunan Kata)}

Berdasarkan tabel di atas diketahui kesalahan Word Order (sususnan kata) dalam penulisan abstrak sebesar $43,3 \%$ dari 30 abstrak yang diteliti. Ini berarti dari 30 responden terdapat 13 responden yang melakukan jenis kesalahan ini.

Contoh kesalahan Word Order (sususnan kata) dalam penulisan abstrak:

Salah: This research was aimed to explore the quality of the program implementation of the Field Schooling Program.

Benar: This research was aimed to explore the quality of the implementation program of the Field Schooling Program.

\section{Redundancy (Pengulangan Kata)}

Berdasarkan tabel di atas diketahui kesalahan Redundancy (Pengulangan Kata) dalam penulisan abstrak sebesar $10 \%$ dari 30 abstrak yang diteliti. Ini berarti dari 30 responden terdapat 3 responden yang melakukan jenis kesalahan ini.

$$
\text { Contoh kesalahan }
$$

Redundancy

(Pengulangan Kata) dalam penulisan abstrak:

Salah: ........ to produce more higher than $\mathrm{CO} 2$.

Benar: ........ to produce higher than CO2.............

\section{Addition (Penambahan Kata)}

Berdasarkan tabel di atas diketahui kesalahan Addition (Penambahan Kata) dalam penulisan abstrak sebesar 33,3\% dari 10 abstrak yang diteliti. Ini berarti dari 30 responden terdapat 3 responden yang melakukan jenis kesalahan ini.

Contoh kesalahan Addition (Penambahan Kata) dalam penulisan abstrak:

Salah: OLAP is a computer based process that enables the users to refer to the data from any point of view.

Benar: OLAP is a computer based process that enables the users to refer the data from any point of view.

\section{Omission (Penghilangan Kata)}

Berdasarkan tabel di atas diketahui kesalahan Omission (Penghilangan Kata) dalam penulisan abstrak sebesar 53,3\% dari 30 abstrak yang diteliti. Ini berarti dari 30 responden terdapat 16 responden yang melakukan jenis kesalahan ini.

Contoh kesalahan Omission (Penghilangan Kata) dalam penulisan abstrak:
Salah: The purpose of the research to find the most effective strain of entomopathogenic nematodes and fungi to control S. Litura.

Benar: The purpose of the research was to find the most effective strain of entomopathogenic nematodes and fungi to control S. Litura.

\section{KESIMPULAN}

Berdasarkan hasil analisis kesalahan gramatikal dalam penulisan abstrak berbahasa Inggris oleh dosen di lingkungan Politeknik Negeri Jember, maka peneliti dapat mengambil kesimpulan bahwa masih banyak dosen yang melakukan kesalahan-kesalahan dalam penulisan abstrak antara lain adalah sebagai berikut:

1. Kesalahan gramatikal yang paling banyak terjadi dalam penulisan abstrak berbahasa Inggris oleh dosen di lingkungan Politeknik Negeri Jember adalah tentang penulisan Article (Kata Sandang) sebanyak 56,7\%.

2. Kesalahan lain yang sering terjadi adalah Preposition (Kata Depan) dan Omission (Penghilangan Kata) sebanyak 53,3\%,

3. Kesalahan yang jarang terjadi adalah Parallelism (Kesejajaran) dan sebanyak Regularization (Penyamaan Aturan)

4. Terdapat pengaruh bahasa Ibu (Native Language) atau bahasa pertama (first language) yang timbul dalam penulisan bahasa Inggris sebagai bahasa asing (foreign language).

\section{SARAN}

Setelah penelitian ini dilaksanakan, yaitu Analisis Kesalahan Gramatikal Penulisan Abstrak Berbahasa Inggris pada Beberapa Jurnal di Lingkungan Politeknik Negeri Jember, maka penulis menyarankan beberapa hal anatara lain:

1. Para dosen diharapkan mempunyai motivasi untuk meningkatkan kemampuan bahasa Inggrisnya khususnya tentang grammar (tata bahasa) dan ketrampilan menulis (writing) sehingga dapat mengurangi kesalahankesalahan dalam penulisan abstrak berbahasa Inggris.

2. Politeknik Negeri Jember mengadakan in house training (pelatihan di dalam khusus bagi para dosen) untuk meningkatkan kemampuan dan ketrampilan bahasa Inggris khususnya tentang grammar (tata bahasa) dan ketrampilan menulis (writing).

3. Karena adanya pengaruh bahasa pertama (first language) terhadap keslahan-kesalahan tersebut maka disarankan ada penelitian lanjutan untuk mengetahui pengaruh bahasa pertama (first language) terhadap kesalahan 
grammatikal dalam penulisan abstrak berbahasa Inggris.

2. Para dosen yang menulis abstrak dalam bahasa Inggris hendaknya memperhatikan aturanaturan gramatikal bahasa Inggris yang meliputi Part of Speech (Jenis Kata), Subject/Verb Agreement (Kesesuaian Subyek dan Kata Kerja), Preposition (Kata Depan), Pronoun Agreement (Kata Ganti), Passive Construction (Kalimat Pasif), Possessive (Kata Ganti Milik), Colon (Tanda Baca), Parallelism (Kesejajaran), Run-on Sentence (Penggabungan Kalimat), Fragments (Kalimat Tidak Lengkap), Article (Kata Sandang), Spelling (Pengejaan), Regularization (Penyamaan Aturan), Verb Tense (Kata Kerja Waktu), Word Choice (Pilihan Kata), Singular/Plural (Tunggal/Jamak), Word Order (Penyusunan Kata), Redundancy (Pengulangan Kata), Addition (Penambahan Kata) dan Omission (Penghilangan Kata).

\section{DAFTAR PUSTAKA}

Blanchard, K \& Root, C 1997. Ready to Writemore: from Paragraph to Essay . New York: Addison- Wesleypublishing Company: Longman Publisher Group.

Brown, H. Douglas. 1994. Teaching by Principles, an Interactive Approach to Language Pedagogy. New Jersey
Crystal, D. 1981. What is Linguistics? Third edition. University of Reading: Edward Arnold.

Dulay, H., Burt, M., \& Krashen, S. 1982. Language Two Oxford University Press.

Huang, W. 1977. Contrastive Analysis, Error Analysis and Teaching English to be Chinese Students. Unpublished M.A. Thesis. NTU.

Hasyim, S. 2002. Error analysis in the teaching of English, (1), pp 42- 50.

Ingale, G.D. 2013 Experimentation with Language in Indian Writing in English. Reviews of Literature • Volume 1 Issue 2.

King, C. E. \& Nancy A. S. 1999. Building Skills for the TOEFL, Edinburgh EH: Thomas Nelson and Sons Ltd.

Ridha, N.S.A. 2012. The Effect of EFL Learners' Mother Tongue on their Writings in English : An Error Analysis Study. Journal of the College of Arts. University of Basrah No. (60).

Safraz, S. 2011. Error Analysis of the Written English Essays of Pakistani. Pakistan: ASTNational University of Computer and Emerging Sciences.

Yulianti. 2007. Analysis of Grammatical Error in Writing.

http://cupep.blogspot.com/2010/01/skripsianalysis-of-grammatical-error/.

Retrieved May10, 2011. 
